\title{
Genotoxic and Genoprotective Potential of Black Mulberry (Morus nigra) Fruit
}

\author{
SERKAN YILMAZ ${ }^{1}$, ASLI UÇAR ${ }^{2}$ and BAYRAM GÖKTAŞ ${ }^{1}$ \\ ${ }^{1}$ Ankara University Faculty of Health Sciences, Department of Midwifery, \\ Fatih Caddesi, 197/A, 06290 Keçiören,Ankara, Turkey \\ ${ }^{2}$ Ankara University Faculty of Health Sciences, Department of Nutrition and \\ Dietetics, Fatih Caddesi ,197/A, 06290,Keçiören,Ankara,Turkey
}

Manuscript received on January 24, 2019; accepted for publication on May 7, 2019

\begin{abstract}
How to cite: YILMAZ S, UÇAR A AND GÖKTAŞ B. 2019. Genotoxic and Genoprotective Potential of Black Mulberry (Morus nigra) Fruit. An Acad Bras Cienc 91: e20190337. DOI. 10.1590/0001-3765201920190337.
\end{abstract}

\begin{abstract}
Black Mulberry (Morus nigra L.) belongs to Moraceae family. The present study evaluated the possible genotoxic and/or protective activities of black mulberry fruit juice (BMFJ), in vitro, using mitomycin $\mathrm{C}(\mathrm{MMC})$ as a positive control, by chromosomal aberrations and micronucleus assays. Human lymphocytes were treated with BMFJ concentrations alone (1/1, 1/2, 1/4, 1/8 dilutions), pretreatment (49h) $(0.20 \mu \mathrm{g} / \mathrm{ml} \mathrm{MMC+1/1} \mathrm{BMFJ,} 0.20 \mu \mathrm{g} / \mathrm{ml} \mathrm{MMC+1/2}$ diluted BMFJ, $0.20 \mu \mathrm{g} / \mathrm{ml} \mathrm{MMC+1/4} \mathrm{diluted}$ BMFJ, $0.20 \mu \mathrm{g} / \mathrm{ml} \mathrm{MMC+1/8} \mathrm{diluted} \mathrm{BMFJ)} \mathrm{and} \mathrm{simultaneous-treatment} \mathrm{(48h)}(0.20 \mu \mathrm{g} / \mathrm{ml} \mathrm{MMC}+1 / 1$ BMFJ, $0.20 \mu \mathrm{g} / \mathrm{ml} \mathrm{MMC+1/2} \mathrm{diluted} \mathrm{BMFJ,} 0.20 \mu \mathrm{g} / \mathrm{ml} \mathrm{MMC+1/4} \mathrm{diluted} \mathrm{BMFJ,} 0.20 \mu \mathrm{g} / \mathrm{ml} \mathrm{MMC}+1 / 8$ diluted BMFJ). The in vitro results demonstrated that BMFJ showed no genotoxicity, but it significantly decreased chromosomal aberration and micronucleus frequency induced by MMC. Our results showed that all concentrations of BMFJ revealed no genotoxicity but protective activity against genomic changes induced by anti-tumor agent MMC in human lymphocytes. Protective effects of BMFJ on MMC induced chromosomal damages most probably due to its free radical scavenging activity.
\end{abstract}

Key words: Black mulberry, chromosomal aberrations, micronucleus, genotoxicity, anti-genotoxicity.

\section{INTRODUCTION}

The relation between use of plants and health has always been widely known by mankind throughout the centuries. According to the World Health Organization nearly $80 \%$ of the world's population still relies on traditional medicinal care for better health (Farnsworth et al. 1985). Vitamins, polyphenols, terpenoids and isoflavonoids are the major bioactive compounds of plants that possess anti-oxidative, anti-mutagenic, anti-carcinogenic,

Correspondence to: Serkan Yilmaz

E-mail: serkanyilmaz@ankara.edu.tr

ORCid: http://orcid.org/0000-0001-8641-9475 and immunomodulating properties (Craig et al. 1999, Santos-Cervantes et al. 2007, Karamova et al. 2011). Since many plant components possess different pharmacological properties for the prevention or treatment of diseases (JiménezMedina et al. 2006), interest on anti-genotoxic, anti-carcinogenic activity of plant extracts has been risen during the past few years. Plant components are generally retard oxidative degradation of lipids and other biomolecules and/or sweep up free radicals generated by mitochondrial oxidative metabolism as well as in cellular response to xenobiotics, cytokines, and bacterial invasion in cell. Oxidative stress causes macromolecular 
damage and is implicated in various diseases such as atherosclerosis, diabetes, cancer, neurodegeneration and aging (Barcelos et al. 2007).

Black Mulberry (Morus nigra), belongs to the Moraceae family (Boschini 2002) and grow up in East, West and South-East Asia, South Europe, South of North America, Northwest of South America and some areas of Africa (Calín-Sánchez et al. 2013) and also in Turkey. The cultivation for fruit production of mulberry reaches nearly 80.000 tons per year (Ercişli and Orhan 2007). Fruit, leaves and even branches of black mulberry are traditionally used as antipyretic, diuretic, lowering blood pressure in various countries (Zhishen et al. 1999). The main bioactive compounds of Black Mulberry fruit have been widely studied in the literature. It is a rich source of phenolic compounds including flavonoids, anthocyanins, phenolic acids and carotenoids (Lin and Tang 2007, Du et al. 2008, Özgen et al. 2009, Kutlu et al. 2011, Fazaeli et al. 2012, Calín-Sánchez et al. 2013). Bae and Suh (2007) reported that anthocyanins are the powerful bioactive components of black mulberry. Gundogdu et al. (2011) deeply investigated the phenolic compound contents, vitamin $\mathrm{C}$ (ascorbic acid) content and total antioxidant capacity (Table I ). Chlorogenic acid and rutin was to be found the highest value of phenolic content.

Recently, studies have shown that the extracts of this plant have strong antioxidant activity because of high phenolic and anthocyanin contents (Gerasopoulos and Stavroulakis 1997, Zhishen et al. 1999, Kutlu et al. 2011). The extract of the black mulberry prevents cell from the lipid oxidation and bio-membranes from peroxidative damage (Naderi et al. 2004), especially flavonoids protect DNA from oxidative damage and effective on enzymes that promotes cancer development (Kris-Etherton et al. 2002). Black mulberry fruit has also possess laxative, odontalgic, antihelmintic, expectorant, hypoglycemic and antimicrobial effects (Mandal and Kumar 2002, Kone et al. 2004, Lin and Tang 2007, Ozgen et al. 2009).

There is scanty report on genotoxicity and anti-genotoxicity of BMFJ has been published in the literature. Therefore, in this study we report the genotoxic and geno-protective activity of BMFJ using cultured human peripheral blood lymphocytes. The use of CAs and MN assays provides useful tools to detect potential genotoxicity

TABLE I

Phenolic compound content, vitamin C (ascorbic acid) content and total antioxidant capacity of black mulberry fruit (from Gundogdu et al. 2011).

\begin{tabular}{cc}
\hline \multicolumn{2}{c}{ Black mulberry (Morus nigra L.) fruit content } \\
\hline Vitamin C $\left({\left.\mathrm{mg} 100 \mathrm{~g}^{-1} \mathrm{fw}\right)}^{-1} \mathrm{fw}\right)$ & $11.302 \pm 0.241$ \\
Total Antioxidant Capacity $(\mu \mathrm{mol} \mathrm{TE} \mathrm{g}$ & $13.999 \pm 0.008$ \\
Gallic acid $\left(\mathrm{mg} \mathrm{g}^{-1} \mathrm{fw}\right)$ & $0.150 \pm 0.003$ \\
Catechin $\left(\mathrm{mg} \mathrm{g}^{-1} \mathrm{fw}\right)$ & $0.075 \pm 0.000$ \\
Chlorogenic acid $\left(\mathrm{mg} \mathrm{g}^{-1} \mathrm{fw}\right)$ & $3.106 \pm 0.004$ \\
Caffeic acid $\left(\mathrm{mg} \mathrm{g}^{-1} \mathrm{fw}\right)$ & $0.131 \pm 0.001$ \\
Syringic acid $\left(\mathrm{mg} \mathrm{g}^{-1} \mathrm{fw}\right)$ & $0.103 \pm 0.000$ \\
p-Coumaric acid $\left(\mathrm{mg} \mathrm{g}^{-1} \mathrm{fw}\right)$ & $0.129 \pm 0.002$ \\
Ferulic acid $\left(\mathrm{mg} \mathrm{g}^{-1} \mathrm{fw}\right)$ & $0.064 \pm 0.001$ \\
o-Coumaric acid $\left(\mathrm{mg} \mathrm{g}^{-1} \mathrm{fw}\right)$ & $0.134 \pm 0.001$ \\
Phloridzin $\left(\mathrm{mg} \mathrm{g}^{-1} \mathrm{fw}\right)$ & $0.031 \pm 0.001$ \\
Protocatechuic acid $\left(\mathrm{mg} \mathrm{g}^{-1} \mathrm{fw}\right)$ & $0.017 \pm 0.000$ \\
Vanilic acid $\left(\mathrm{mg} \mathrm{g}^{-1} \mathrm{fw}\right)$ & $0.036 \pm 0.002$ \\
Rutin $\left(\mathrm{mg} \mathrm{g}^{-1} \mathrm{fw}\right)$ & $1.423 \pm 0.036$ \\
Quercetin $\left(\mathrm{mg} \mathrm{g}^{-1} \mathrm{fw}\right)$ & $0.113 \pm 0.021$ \\
\hline
\end{tabular}


and anti-genotoxicity of environmental mutagens and other chemicals.

\section{MATERIALS AND METHODS}

Black Mulberries at full mature stage were collected from the Balıkesir province in Turkey and deposited in our Department (voucher specimen number: 2015FHS38). Chromosome medium B was obtained from Biochrome. Mitomycin C (CAS No: 200-008-6), cytochalasin B (CAS No: 1493096-2) was obtained from Sigma. Other chemicals was obtained from Sigma (USA).

Before experiments ethical approval was obtained from local ethic committee (Reg. No: 17-195). Peripheral venous blood was collected from non-smoking healthy 2 females and 2 males adults (aged 25-26 years). Whole blood $(0.2 \mathrm{ml})$ was added to $2.5 \mathrm{ml}$ Chromosome Medium B. Cultures were incubated at $37{ }^{\circ} \mathrm{C}$ for $72 \mathrm{~h}$. Test substance was added after $24 \mathrm{~h}$ and $23 \mathrm{~h}$ of culture initiation. Human lymphocytes were exposed to BMFJ concentrations alone $(1 / 1,1 / 2,1 / 4,1 / 8$ dilutions), pretreatment (49h) $(0.20 \mu \mathrm{g} / \mathrm{ml} \mathrm{MMC+}$ 1/1 BMFJ, $0.20 \mu \mathrm{g} / \mathrm{ml} \mathrm{MMC+1/2} \mathrm{diluted} \mathrm{BMFJ,}$ $0.20 \mu \mathrm{g} / \mathrm{ml} \mathrm{MMC}+1 / 4$ diluted BMFJ, $0.20 \mu \mathrm{g} /$ $\mathrm{ml} \mathrm{MMC}+1 / 8$ diluted BMFJ) and simultaneoustreatment (48h) $(0.20 \mu \mathrm{g} / \mathrm{ml} \mathrm{MMC}+1 / 1 \mathrm{BMFJ}$, $0.20 \mu \mathrm{g} / \mathrm{ml} \mathrm{MMC}+1 / 2$ diluted BMFJ, $0.20 \mu \mathrm{g} / \mathrm{ml}$ $\mathrm{MMC}+1 / 4$ diluted BMFJ, $0.20 \mu \mathrm{g} / \mathrm{ml} \mathrm{MMC}+1 / 8$ diluted BMFJ). Negative and positive control (MMC, $0.20 \mu \mathrm{g} / \mathrm{ml}$ ) were also included in the test. Colchicine was added to arrest mitosis in the metaphase stage at a concentration of $0.06 \mu \mathrm{g} / \mathrm{ml}$ at $70^{\text {th }} \mathrm{h}$ of the culture. At the end of the culture period, the cells were collected by centrifugation (1200 rpm, $10 \mathrm{~min}$ ), re-suspended in a hypotonic solution (KCI, $0.075 \mathrm{M}$ ) for $30 \mathrm{~min}$ at $37{ }^{\circ} \mathrm{C}$ and fixed in cold methanol acetic acid (3:1) for $20 \mathrm{~min}$ at room temperature. The treatment with fixative was repeated 3 times. Finally, metaphase spreads were prepared by dropping the concentrated cell suspension onto slides. Air dried slides were stained with 5\% Giemsa (pH. 6.8) prepared in Sorensen buffer solution for $20 \mathrm{~min}$ and mounted with DPX. A hundred well spread metaphases, totally 400 metaphases per concentration, were analyzed for the CA assays per donor.

For micronucleus analysis, human lymphocyte culture was incubated at $37^{\circ} \mathrm{C}$ for $72 \mathrm{~h}$ and $44 \mathrm{~h}$ from the initiation; cytochalasin B (Cyt-B) at a final concentration of $5.2 \mu \mathrm{g} / \mathrm{ml}$ was added to block cytokinesis. Human lymphocytes were exposed to BMFJ concentrations alone $(1 / 1,1 / 2,1 / 4,1 / 8$ dilutions), pre-treatment (49h) $(0.20 \mu \mathrm{g} / \mathrm{ml} \mathrm{MMC}+$ 1/1 BMFJ, $0.20 \mu \mathrm{g} / \mathrm{ml} \mathrm{MMC+1/2} \mathrm{diluted} \mathrm{BMFJ,}$ $0.20 \mu \mathrm{g} / \mathrm{ml} \mathrm{MMC}+1 / 4$ diluted BMFJ, $0.20 \mu \mathrm{g} /$ $\mathrm{ml} \mathrm{MMC}+1 / 8$ diluted BMFJ) and simultaneoustreatment (48h) $(0.20 \mu \mathrm{g} / \mathrm{ml} \mathrm{MMC}+1 / 1 \mathrm{BMFJ}$, $0.20 \mu \mathrm{g} / \mathrm{ml} \mathrm{MMC}+1 / 2$ diluted BMFJ, $0.20 \mu \mathrm{g} / \mathrm{ml}$ $\mathrm{MMC}+1 / 4$ diluted BMFJ, $0.20 \mu \mathrm{g} / \mathrm{ml} \mathrm{MMC}+1 / 8$ diluted BMFJ). Negative and positive control (MMC, $0.20 \mu \mathrm{g} / \mathrm{ml}$ ) were included. Cultures were harvested at $72^{\text {nd }} \mathrm{h}$. Then the cells were treated with cold hypotonic solution (0.075 M KCI for $5 \mathrm{~min}$ ). The cells were fixed with methanol: glacial acetic acid $(3: 1 \mathrm{v} / \mathrm{v})$ supplemented with formaldehyde. Finally, cell spreads were prepared by dropping the concentrated cell suspension onto slides. The slides were air-dried and stained with 5\% Giemsa. Micronuclei were scored from 1000 bi-nucleated cells per donor (totally 4000 bi-nucleated cells per concentration).

For the statistical analysis of the results, z-test for percentage of abnormal cell, CA/cell and MN were used. Dose-response relationships were determined from the correlation and regression coefficients for the percentage of abnormal cell, $\mathrm{CA} /$ cell and mean $\mathrm{MN}$.

\section{RESULTS}

No significant difference in the induction of chromosomal aberrations and micronuclei 
was observed between the groups treated with the concentrations of BMFJ and the negative control. Beyond, the treatment of the cells with BMFJ plus MMC (pre-treatment and simultaneous treatment) showed a significant reduction of chromosomal aberrations when compared to treatment with MMC only (Table II).

The results also showed that BMFJ significantly reduced the frequency of micronuclei (pre-treatment and simultaneous treatment) induced by $\mathrm{MMC}$ at the three concentrations $(1 / 1,1 / 2$ and $1 / 4$ dilutions) tested. Only lowest concentration in simultaneous treatment was not significant (Table III). Our results exhibited that all concentrations of BMFJ showed no genotoxicity but protective activity against genomic changes induced by antitumor agent $\mathrm{MMC}$ in human lymphocytes.

\section{DISCUSSION}

Mitomycin $\mathrm{C}(\mathrm{MMC})$ is an antitumor agent that has been used for a treatment of variety of tumors. However, it has bind covalently to DNA (Tomasz 1995, Paz et al. 2012), and has been shown to alkylate other cellular nucleophiles in addition to DNA, such as glutathione (GSH) (Sharma and Tomasz 1994, Sharma et al. 1994, Paz et al. 2012). Depending on the biotransformation pathway, metabolism of MMC may generate Reactive Oxygen Species (ROS) (Gustafson and Pritsos 1992, Ortega-Gutiérrez et al. 2009). When ROS interact with cells and exceed endogenous antioxidant systems, there is indiscriminate damage to biological macromolecules such as nucleic acids, proteins, and lipids (Offord et al. 2000, OrtegaGutiérrez et al. 2009).

TABLE II

Protective role of black mulberry fruit juice (BMFJ) against MMC induced chromosomal damages in vitro.

\begin{tabular}{|c|c|c|c|c|c|c|c|c|c|c|c|}
\hline \multirow[b]{2}{*}{ Test substance } & \multicolumn{2}{|c|}{ Treatment } & \multicolumn{7}{|c|}{ Aberrations } & \multirow[b]{2}{*}{$\begin{array}{l}\text { Abnormal cell } \\
\quad \pm \text { SE }(\%)\end{array}$} & \multirow[b]{2}{*}{$\begin{array}{c}\text { CA/Cell } \\
\quad \pm \mathrm{SE}\end{array}$} \\
\hline & $\begin{array}{l}\text { Period } \\
\text { (hour) }\end{array}$ & $\begin{array}{c}\text { Dose } \\
(\mu \mathrm{g} / \mathrm{ml}+ \\
\text { dilution) }\end{array}$ & ctb & csb & $\mathbf{f}$ & scu & dic & cte & $\mathbf{p}$ & & \\
\hline \multirow{6}{*}{$\begin{array}{c}\text { Negative Control } \\
\text { MMC } \\
\text { BMFJ }\end{array}$} & & 0.00 & 3 & 1 & 2 & 2 & - & - & - & $2.00 \pm 0.70$ & $0.002 \pm 0.002$ \\
\hline & 48 & 0.20 & 68 & 21 & 12 & 7 & 14 & 16 & - & $30.00 \pm 2.29$ & $0.345 \pm 0.023$ \\
\hline & 48 & $1 / 1$ & 2 & 2 & 3 & 5 & 1 & - & 1 & $3.50 \pm 0.92$ & $0.035 \pm 0.009$ \\
\hline & 48 & $1 / 2$ & 4 & - & 1 & 3 & - & - & - & $2.00 \pm 0.70$ & $0.020 \pm 0.007$ \\
\hline & & $1 / 4$ & 1 & 1 & 2 & 1 & - & - & - & $1.25 \pm 0.56$ & $0.013 \pm 0.006$ \\
\hline & & $1 / 8$ & 2 & 2 & - & 3 & - & - & - & $1.75 \pm 0.66$ & $0.018 \pm 0.007$ \\
\hline \multirow{4}{*}{$\begin{array}{l}\text { MMC+BMFJ (pre- } \\
\text { treatment) }\end{array}$} & & $0.20+1 / 1$ & 23 & 7 & - & 8 & 5 & 6 & 1 & $11.75 \pm 1.61^{* *}$ & $0.125 \pm 0.017 * *$ \\
\hline & 49 & $0.20+1 / 2$ & 29 & 11 & 3 & 7 & 8 & 5 & - & $15.00 \pm 1.79^{* *}$ & $0.158 \pm 0.018^{* *}$ \\
\hline & & $0.20+1 / 4$ & 42 & 10 & 8 & - & 6 & 9 & - & $17.50 \pm 1.90 * *$ & $0.188 \pm 0.020 * *$ \\
\hline & & $0.20+1 / 8$ & 53 & 6 & 5 & 6 & 7 & 11 & 1 & $21.25 \pm 2.05^{* *}$ & $0.223 \pm 0.021 * *$ \\
\hline \multirow{4}{*}{$\begin{array}{c}\text { MMC+BMFJ } \\
\text { (simultaneous- } \\
\text { treatment) }\end{array}$} & & $0.20+1 / 1$ & 31 & 11 & 6 & - & 3 & 9 & - & $15.00 \pm 1.79 * *$ & $0.150 \pm 0.018^{* *}$ \\
\hline & 48 & $0.20+1 / 2$ & 26 & 6 & 7 & 12 & 5 & 12 & 2 & $17.50 \pm 1.90^{* *}$ & $0.175 \pm 0.019^{* *}$ \\
\hline & & $0.20+1 / 4$ & 44 & 9 & 9 & 19 & 7 & 9 & - & $22.75 \pm 2.10 *$ & $0.243 \pm 0.021 *$ \\
\hline & & $0.20+1 / 8$ & 49 & 12 & 9 & 11 & 8 & 15 & - & $24.50 \pm 2.15^{*}$ & $0.260 \pm 0.022 *$ \\
\hline
\end{tabular}

ctb: chromatid break, csb: chromosome break, f: fragment, scu: sister chromatid union, dic: dicentric, cte: chromatid exchange, $\mathrm{p}$ : polyploidy. 400 metaphases were scored for each treatment.

* Significantly different from the MMC $\mathrm{P}<0.01$.

** Significantly different from the MMC $\mathrm{P}<0.001$. 
TABLE III

Protective role of black mulberry fruit juice (BMFJ) against MMC induced micronuclei in vitro.

\begin{tabular}{|c|c|c|c|c|c|c|c|c|}
\hline \multirow{3}{*}{ Test substance } & \multicolumn{2}{|c|}{ Treatment } & \multirow{3}{*}{$\begin{array}{c}\text { Binucleated } \\
\text { cells }(\mathrm{BN}) \\
\text { scored }\end{array}$} & \multirow{2}{*}{\multicolumn{4}{|c|}{$\begin{array}{l}\text { Distribution of } \mathrm{BN} \text { cells } \\
\text { according to the no. of } \mathrm{MN}\end{array}$}} & \multirow{3}{*}{$\begin{array}{l}\text { MN } \\
(\%)\end{array}$} \\
\hline & \multirow{2}{*}{$\begin{array}{l}\text { Period } \\
\text { (hour) }\end{array}$} & \multirow{2}{*}{$\begin{array}{c}\text { Dose } \\
(\mu \mathrm{g} / \mathrm{ml}+ \\
\text { dilution) }\end{array}$} & & & & & & \\
\hline & & & & (1) & (2) & (3) & (4) & \\
\hline \multirow[b]{2}{*}{ Negative Control } & & 0.00 & 4000 & 10 & - & - & - & $0.25 \pm 0.0070$ \\
\hline & 48 & 0.20 & 4000 & 43 & 6 & 2 & 1 & $1.63 \pm 0.0003$ \\
\hline \multirow{4}{*}{$\begin{array}{l}\text { MMC } \\
\text { BMFJ }\end{array}$} & 48 & $1 / 1$ & 4000 & 7 & - & - & - & $0.18 \pm 0.0060$ \\
\hline & 48 & $1 / 2$ & 4000 & 8 & - & - & - & $0.20 \pm 0.0063$ \\
\hline & & $1 / 4$ & 4000 & 7 & 1 & - & - & $0.23 \pm 0.0067$ \\
\hline & & $1 / 8$ & 4000 & 11 & 1 & - & - & $0.33 \pm 0.0074$ \\
\hline \multirow{4}{*}{$\begin{array}{l}\text { MMC+BMFJ } \\
\text { (pre-treatment) }\end{array}$} & & $0.20+1 / 1$ & 4000 & 16 & - & - & - & $0.40 \pm 0.0077 * * *$ \\
\hline & 49 & $0.20+1 / 2$ & 4000 & 23 & - & - & - & $0.58 \pm 0.0078 * * *$ \\
\hline & & $0.20+1 / 4$ & 4000 & 20 & 2 & - & - & $0.60 \pm 0.0077 * * *$ \\
\hline & & $0.20+1 / 8$ & 4000 & 32 & 1 & 1 & - & $0.93 \pm 0.0040^{*}$ \\
\hline \multirow{4}{*}{$\begin{array}{c}\text { MMC+BMFJ } \\
\text { (simultaneous-treatment) }\end{array}$} & & $0.20+1 / 1$ & 4000 & 16 & 1 & - & - & $0.45 \pm 0.0078^{* * *}$ \\
\hline & 48 & $0.20+1 / 2$ & 4000 & 22 & 1 & - & - & $0.60 \pm 0.0077 * * *$ \\
\hline & & $0.20+1 / 4$ & 4000 & 28 & 1 & 1 & - & $0.83 \pm 0.0060^{* *}$ \\
\hline & & $0.20+1 / 8$ & 4000 & 40 & - & 1 & 1 & $1.18 \pm 0.0073$ \\
\hline
\end{tabular}

* Significantly different from the MMC $\mathrm{P}<0.05$.

** Significantly different from the MMC $\mathrm{P}<0.01$.

*** Significantly different from the MMC $\mathrm{P}<0.001$.

Black mulberry (Morus nigra) fruit has a high nutrient content, especially of antioxidants (Naderi et al. 2004). It has the highest acidity, reduced ascorbic acid, $\mathrm{Fe}++$, total flavonoids, and total monomeric anthocyanins (especially Cyanidin) (Jiang and Nie 2015, Veberic et al. 2015). Extracts of mulberry fruits were found to possess free radical scavenging activity, anti-hyperlipidemia, anti-atherogenic properties and neuroprotective effects and anti-cancer effects (human lung cancer cell line A549) (Chen et al. 2005, 2006, Kang et al. 2006, Bae and Suh 2007, Jiang and Nie 2015).

Aydin et al. (2015) reported that no statistically significant difference was observed in the hepatic lipid fractions of rats containing $M$. nigra fruit extract. However, the level of lipid peroxidation were found to be very low in M. nigra treated group (Aydin et al. 2015). Anticancer activity of M. nigra on human breast cancer cell line (MCF-
7) was investigated by Ahmed et al. (2016). Black mulberry (BM) extracts administration gave significant morphological evidence of apoptosis and increased cell death after 48 hours more than that of 24 hours-treated MCF-7 cells among fresh and dry extract groups. DNA analysis after $24 \mathrm{~h}$ of $\mathrm{BM}$ extracts treated groups has no fragmentation while apoptosis is generated after $48 \mathrm{~h}$ showing more fragmentation in fresh BM groups. The mitotic index records were significantly decreased in dose and time dependent manner showing the better anti-proliferative effect with fresh extract treatments. DNA single strand breaks were also increased among the treatment groups at dose and time dependent manner with the best results with fresh extract.

Ghasemnezhad Targhi et al. (2017) investigated the radio protective effect of black mulberry extract on liver tissue and bone marrow cells in the rat. 200 
$\mathrm{mg} / \mathrm{kg}$ extract significantly reduced the frequencies of micronucleated polychromatic erythrocytes and micronucleated normochromatic erythrocytes, it also decreased the level of malondialdehyde and superoxide dismutase, as well as enhanced the total thiol content and catalase activity in rat's liver. Authors concluded that black mulberry extract reduced the genotoxicity and cytotoxicity induced by gamma irradiation in bone marrow cells and liver in the rat. Turan et al. (2017) evaluated the antiproliferative and apoptotic effect of $M$. nigra extract on human prostate cancer cells. Authors reported that $M$. nigra extract arrested the cell cycle of PC-3 cells at the G1 phase, induced apoptosis via increased caspase activity and reduced mitochondrial membrane potential. In another study statistically no significant difference was observed in the hepatic lipid fractions of rats containing $M$. nigra fruit extract. However, the level of lipid peroxidation were found to be very low in M. nigra treated group (Aydin et al. 2015). Volpato et al. (2011) reported that M. nigra leaf aqueous extract had antioxidant effect, contributing to reduce incidence of internal anomalies in offspring from diabetic rat dams. Kutlu et al. (2011) informed that acidified extract of black mulberry was higher in $\beta$-carotene prevention and DPPH radical scavenging activity than non-acidified extract. However, non-acidified extract represented a higher reducing power and metal chelating activity, and a higher content of total phenolics.

As shown in the Table II no significant difference in the induction of chromosomal aberrations was observed between the groups treated with the concentrations of BMFJ and the negative control. Beyond, the treatment of the cells with BMFJ plus MMC (pre-treatment and simultaneous treatment) showed a significant reduction of chromosomal aberrations when compared to treatment with MMC only (Table II). A relationship between chromosomal damage and cancer development has been suggested since the beginning of the $20^{\text {th }}$ century (Ribbert et al. 1914, Bonassi et al. 2000), and now we clearly know that increased frequency of chromosomal aberrations cause cancer development because of genomic imbalance.

BMFJ has also significantly reduced the frequency of micronuclei (pretreatment and simultaneous treatment) induced by MMC at the three concentrations $(1 / 1,1 / 2$ and $1 / 4$ dilutions $)$ tested. The in vitro micronucleus test detects genotoxic effects of xenobiotics in cells and predicts cancer development (Bonassi et al. 2011). Our results showed that all concentrations of BMFJ indicated no genotoxicity but protective activity against genomic changes induced by anti-tumor agent MMC in human lymphocytes. Protective effects of BMFJ on MMC induced chromosomal damages most probably due to its free radical scavenging activity.

\section{ACKNOWLEDGMENTS}

The authors have thanks to the Recep Özbudak and Fehmi Doğançay who provides black mulberry fruits.

\section{AUTHOR CONTRIBUTIONS}

SY supervised the research, designed and performed experiments, analyzed data and co-wrote the paper. AU performed experiments and co-wrote the paper. BG collected samples, analyzed data and co-wrote the paper.

\section{REFERENCES}

AHMED A, ALİ M, EL-KHOLIE E, EL-GARAWANI I AND SHERIF N. 2016. Anticancer activity of Morus nigra on human breast cancer cell line (MCF-7): the role of fresh and dry fruit extracts. J Biosci App Res 2: 352-361.

AYDIN S, YILMAZ Ö AND GÖKÇE Z. 2015. Protective Effect of Morus nigra L. (Mulberry) Fruit Extract on the Liver Fatty Acid Profile of Wistar Rats. Pakistan J Zool 47(1): 255-261.

BAE SH AND SUH HJ. 2007. Antioxidant Activities of five different mulberry cultivars in Korea. LWT-Food Sci Tech 40(6): 955-962. 
BARCELOS GRM, SHIMABUKURO F, MACIEL MAM AND CÓLUS IM. 2007. Genotoxicity and antigenotoxicity of cashew (Anacardium occidentale L.) in V79 cells. Toxicol In Vitro 21(8): 1468-1475.

BONASSI S, EL-ZEIN R, BOLOGNESI C AND FENECH M. 2011. Micronucleus frequency in peripheral blood lymphocytes and cancer risk: evidence from human studies. Mutagenesis 26: 93-100.

BONASSI S ET AL. 2000. Chromosomal aberrations in lymphocytes predict human cancer independently of exposure to carcinogens. European Study Group on Cytogenetic Biomarkers and Health. Cancer Res 60(6): 1619-1625.

BOSCHINI CF. 2002. Nutritional quality of mulberry cultivated for ruminant feeding. In: Mulberry for Animal Production. Sanchez MD (Ed), FAO Animal Production and Health Paper. No: 147. FAO, Rome, Italy, p. 171-180.

CALÍN-SÁNCHEZ Á, MARTÍNEZ-NİCOLÁS JJ, MUNERA-PICAZO S, CARBONELL-BARRACHINA ÁA, LEGUA P AND HERNÁNDEZ F. 2013. Bioactive Compounds and Sensory Quality of Black and White Mulberries Grown in Spain. Plant Foods Hum Nutri 68(4): 370-377.

CHEN CC, LIU LK, HSU JD, HUANG HP, YANG MY AND WANG CJ. 2005. Mulberry extract inhibits the development of atherosclerosis in cholesterol-fed rabbits. Food Chem 91(4): 601-607.

CHEN PN, CHU SC, CHIOU HL, KUO WH, CHIANG CL AND HSIEH YS. 2006. Mulberry anthocyanins cyanidin 3-rutinoside and cyaniding 3-glucoside exhibited an inhibitory effect on the migration and invasion of a human lung cancer cell line. Cancer Lett 235(2): 248-259.

CRAIG WJ. 1999. Health-Promoting Properties of Common Herbs. Am J Clin Nutri 70(3 Suppl.): 491S-499S.

DU Q, ZHENG J AND XU Y. 2008. Composition of anthocyanins in mulberry and their antioxidant activity. $\mathrm{J}$ Food Comp An 21(5): 390-395.

ERCIŞLİ S AND ORHAN E. 2007. Chemical composition of white (Morus alba), red (Morus rubra) and black (Morus nigra) mulberry fruits. Food Chem 103(4): 1380-1384.

FARNSWORTH NR, AKERELE OO, BINGEL AS, SOEJARTA DD AND ENO Z. 1985. Medicinal plants in therapy. Bull WHO 63(6): 965-981.

FAZAELI M, EMAM-DJOMEH Z, KALBASI-ASHTARI A AND OMID M. 2012. Effects of heating method and conditions on the quality attributes of black mulberry (Morus nigra) juice concentrate. Int J Food Eng 46(5): 956-962.

GERASOPOULOS D AND STAVROULAKIS G. 1997. Quality characteristics of four mulberry (Morus sp.) cultivars in the area of Chania, Greece. J Sci Food Agri 73(2): 261-264.
GHASEMNEZHAD TR, HOMAYOUN M, MANSOURI S, SOUKHTANLOO M, SOLEYMANIFARD S AND SEGHATOLESLAM M. 2017. Radio protective effect of black mulberry extract on radiation-induced damage in bone marrow cells and liver in the rat. Rad Phys Chem 130: 297-302.

GUNDOGDU M, MURADOGLUA F, GAZIOGLU SENSOY RI AND YILMAZ H. 2011. Determination of fruit chemical properties of Morus nigra L., Morus alba L. and Morus rubra L. by HPLC. Scientia Hor 132: 37-41.

GUSTAFSON DL AND PRITSOS CA. 1992. Oxygen radical generation and alkylating ability of mitomycin $\mathrm{C}$ bioactivated by xanthine dehydrogenase. Proc West Pharmacol Soc 35: 147-151.

JIANG Y AND NIE WJ. 2015. Chemical properties in fruits of mulberry species from the Xinjiang province of China. Food Chem 174: 460-466.

JIMÉNEZ-MEDINA E, GARCIA-LORA A, PACO L, ALGARRA I, COLLADO A AND GARRIDO F. 2006. A new extract of the plant Calendula oficinalis produces a dual in vitro effect: Cytotoxic anti-tumor activity and lymphocyte activation. BMC Cancer 6: 119.

KANG TH, HUR JY, KIM HB, RYU JH AND KIM SY. 2006. Neuroprotective effects of the cyanidin-3-O-betad-glucopyranoside isolated from mulberry fruit against cerebral ischemia. Neurosci Lett 391(3): 122-126.

KARAMOVA NS, FATYKHOVA DG, ABDRAKHIMOVA YR AND IL'INSKAYA ON. 2011. An Investigation Of Antigenotoxic Properties Of Plant Extracts Of Chelidonium majus L., Plantago major L. and Tussilago farfara L. Russ J Gen 1: 371-378.

KONÉ WM, ATINDEHOU KK, TERREAUX C, HOSTETTMANN K, TRAORÉ D AND DOSSO M. 2004. Traditional medicine in North Cote d'Ivoire: screening of 50 medicinal plants for antibacterial activity. J Ethnopharmacol 93(1): 43-49.

KRIS-ETHERTON PM, HECKER KD, BONANOME A, COVAL SM, BINKOSKI AE, HILPERT KF, GRIEL AE AND ETHERTON TD. 2002. Bioactive compounds in foods: their role in the prevention of cardiovascular disease and cancer. Am J Med 113(Suppl. 9B): 71S-88S.

KUTLU T, DURMAZ G, ATEŞ B, YILMAZ İ AND ÇETIN MŞ. 2011. Antioxidant properties of different extracts of black mulberry (Morus nigra L.). Turk J Biol 35: 103-110.

LIN JY AND TANG CY. 2007. Determination of total phenolic and flavonoid contents in selected fruits and vegetables, as well as their stimulatory effects on mouse splenocyte proliferation. Food Chem 101: 140-147.

MANDAL SC AND KUMAR CKA. 2002. Studies on antidiarrhoeal activity of Ficus hispida Leaf extract in rats. Fitoterapia 73(7-8): 663-667.

NADERI GA, ASGARY S, SARRAF-ZADEGAN N, OROOJY H AND AFSHIN-NIA F. 2004. Antioxidant 
activity of three extracts of Morus nigra. Phytother Res 18 (5): 365-369.

OFFORD E, VAN POPPEL G AND TYRRELL R. 2000. Markers of oxidative damage and antioxidant protection: current status and relevance to disease. Free Radic Res 33(Suppl): 5S-19S.

ORTEGA-GUTIÉRREZ S, LÓPEZ-VICENTE M, LOSTALÉ F, FUENTES-BROTO L, MARTÍNEZ-BALLARÍN E AND GARCÍA JJ. 2009. Protective effect of melatonin against mitomycin $\mathrm{C}$-induced genotoxic damage in peripheral blood of rats. J Biomed Biotech Article ID: 79143279: 1-6.

OZGEN M, SERCE S AND KAYA C. 2009. Phytochemical and antioxidant properties of anthocyanin rich Morus nigra and Morus rubra fruits. Scientia Horti 119(33): 275-279.

PAZ MM, ZHANG X, LU J AND HOLMGREN A. 2012. A new mechanism of action for the anticancer drug mitomycin C: mechanism-based inhibition of thioredoxin reductase. Chem Res Toxicol 25(7): 1502-1511.

RIBBERT T. 1914. Zur Frage der Entstehung maligner Tumoren. Gustav Fisher (Jena, Germany). 2: 676.

SANTOS-CERVANTES ME, IBARRA-ZAZUETA ME, LOARCA-PIÑA G, PAREDES-LÓPEZ O AND DELGADO-VARGAS F. 2007. Antioxidant and antimutagenic activities of Randia echinocarpa fruit. Plant Foods Hum Nutri 62(2): 71-77.

SHARMA M, HE QY AND TOMASZ M. 1994. Effects of glutathione on alkylation and cross-linking of DNA by mitomycin C. Isolation of a ternary glutathione-mitomycinDNA adduct. Chem Res Toxicol 7(3): 401-407.

SHARMA M AND TOMASZ M. 1994. Conjugation of glutathione and other thiols with bioreductively activated mitomycin C. Effect of thiols on the reductive activation rate. Chem Res Toxicol 7(3): 390-400.

TOMASZ M. 1995. Mitomycin C: Small, fast and deadly (but very selective). Chem Biol 2(9): 575-579.

TURAN I, DEMIR S, KILINC K, BURNAZ NA, YAMAN SO, AKBULUT K, MENTESE A, ALIYAZICIOGLU A AND DEGER O. 2017. Antiproliferative and apoptotic effect of Morus nigra extract on human prostate cancer cells. Saudi Pharm J 25(2): 241-248.

VEBERIC R, SLATNAR A, BIZJAK J, STAMPAR F AND MIKULIC-PETKOVSEK M. 2015. Anthocyanin composition of different wild and cultivated berry species. LWT - Food Sci Tech 60(1): 509-517.

VOLPATO GT, CALDERON IM, SINZATO S, CAMPOS KE, RUDGE MV AND DAMASCENO DC. 2011. Effect of Morus nigra aqueous extract treatment on the maternalfetal outcome, oxidative stress status and lipid profile of streptozotocin-induced diabetic rats. J Ethnopharmacol 138(3): 691-696.

ZHISHEN J, MENGCHENG T AND JIANMING W. 1999. The determination of flavonoid contents in mulberry and their scavenging effects on superoxide radicals. Food Chem 64(4): 555-559. 